\title{
イネの登熟段階と割れ籾の発生がアカヒゲホソミドリカスミカメ幼虫の 発育に及ぼす影響
}

\author{
石本 万寿広 \\ 新潟県農業総合研究所作物研究センター
}

\begin{abstract}
Effects of the Ripening Stage and the Occurrence of Split-hull Paddy of Rice Plant on Development of Nymphs of the Rice Leaf Bug, Trigonotylus caelestialium (Kirkaldy) (Heteroptera: Miridae). Masuhiro IsHiмото Niigata Agricultural Research Institute, Crop Research Center; Nagakura 857, Nagaoka, Niigata 940-0826, Japan. Jpn. J. Appl. Entomol. Zool. 51: 107-114 (2007)
\end{abstract}

\begin{abstract}
To examine the effects of ripening stage and the occurrence of split-hull paddies of rice plants on the development of Trigonotylus caelestialium nymphs, the nymphs were reared on two rice cultivars, Wasejiman and Koshihikari, that exhibit a high and low rate of split-hull paddies, respectively. The nymphs were released on a caged ear with stem and leaf at each of the four rice stages, i.e., at heading and 10, 20 or 30 days after heading, and 10 days after release, the numbers of surviving nymphs, split-hull paddies and injured rice grains were counted. Numbers of split-hull paddies were 0 at the stage of heading and few at 10 days after heading. Survival rates of nymphs were high at the stage of heading and low at 10 days after heading. At 20 and 30 days after heading, Wasejiman exhibited larger numbers of split-hull paddies and supported higher survival rates of $T$. caelestialium nymphs than Koshihikari, although these values varied yearly. There is significant positive correlation between the number of injured rice grains and survival rates of nymphs at these ripening stages, indicating that nymphal development certainly depends on feeding on the rice grains. Most injured grains were found in split-hull paddies, and the survival rates of nymphs were significantly correlated with the number of split-hull paddies. It is considered that nymphs primarily feed on rice grains from the split part of paddies. It is suggested that the occurrence time and the number of split-hull paddies cause fluctuation in the density of $T$. caelestialium nymphs in paddy fields.
\end{abstract}

Key words: Trigonotylus caelestialium; rice leaf bug; split-hull paddy; nymphal development

緒 言

アカヒゲホソミドリカスミカメ Trigonotylus caelestialium (Kirkaldy) は, 北海道, 東北, 北陸地域に打ける斑点米力 メムシ類の主要種である（渡邊・樋口，2006）。水田での すくい取り調査の結果から, 本種は登熟期のイネで 1 世代 を経過することが明らかにされている（奥山・井上，1974； 石本, 2004a)。したがって, 本種成虫は登熟期のイネに産 卵し，この卵に起因する幼虫は成虫まで発育できると考え られる。しかし，イネの品種の違い，年次の違いにより幼 虫の発生が明瞭な場合と, 不明瞭あるいは発生量がごく少 ない場合がある (八谷, 1985; 石本, 2004a). 斑点米はこ の幼虫ならびに引き続き発生する成虫の加害によるものが 主体であり, 幼・成虫数と斑点米率の間に密接な関係があ り (石本, 2004a, b; 石本・永瀬, 2005), 防除対策上は, この幼虫発生量の変動要因を解明することが重要である.
しかし，これまでに登熟期のイネでの幼虫発育に関する報 告はなく, 幼虫発育が可能か否か, その発育にどのような 要因が関係しているかは明らかにされていない.

本種の幼虫は, 籾を吸汁して斑点米を発生させることか ら（奥山・井上, 1974）, 玄米を飭として利用しているこ とは明らかである。最近, 幼虫の飰として玄米が好適であ ることが明らかになり（石本・佐藤, 2006）, 登熟期のイ ネにおいても，立米を吸汁できる条件では，幼虫は十分発 育できると考えられる，穂への成虫放飼試験の結果から， 本種が玄米を吸汁する部位は, 籾頂部の鈎合部と割れ籾の 側面の開穎部が大部分であり, 籾頂部からの加害は籾の登 熟に伴いしだいに困難になるが, 一方, 割れ籾は正常籾に 比べ加害しやすく, 登熟が進んでも加害が可能であるとさ れている（伊藤，2004）。幼虫の放飼試験においても，発 生する斑点米の着色部位は頂部と側部が大部分であること は成虫と共通している（奥山・井上，1974）。したがって， 
幼虫が飭として利用できる籾の種類や数は, 登熟段階や割 れ籾の発生数により変動する可能性が高い. 石本 (2004a) は, 水田でのすくい取り調查結果から, 割れ籾が多い場合 に明瞭な幼虫の発生が認められ，割れ籾の発生が幼虫発育 に関係している可能性を指摘している。 そこで，登熟期の イネを用いて，特に割れ籾の発生に着目して，幼虫の発育 試験を行った。その結果，割れ粐が幼虫の発育に密接に関 係していることが明らかになったので報告する.

本文に先立ち, 本稿を校閲していただいた農業・食品産 業技術総合研究機構中央農業総合研究センター北陸研究セ ンターの樋口博也博士に深く感謝の意を表する.

\section{材料および方法}

\section{1. 供試虫および試験場所}

アカヒゲホソミドリカスミカメは，2003 年に新潟県見附 市で採集し，樋口・高橋（2000）の方法によりコムギ芽出 し苗を慨として累代飼育している系統を用いた。飼育およ び放飼試験は， $25^{\circ} \mathrm{C}, 16 \mathrm{~L}-8 \mathrm{D}$ 条件の室内で行った。

\section{2. 品種, 登熟段階が異なるイネにおける幼虫発育}

品種は, 割れ籾が多い品種として極早生の「わせじま ん」, 割れ籾が少ない品種として中生の「コシヒカリ」を 用いた (石本，2004a）。2004 年は，1/5,000 ワグネルポッ トに 5 月 28 日に播種し, 屋外で栽培したイネを用いた。供 試したイネの出穂日は，「わせじまん」が 8 月 2 日〜3 日， 「コシヒカリ」が 8 月 18 日〜19 日であった。 2005 年, 2006 年は，5月 10 日に稚苗を水田に移植し，出穂前に $1 / 5,000$ ワグネルポットに移し, その後はビニールハウス内で栽培 したイネを用いた。供試したイネの出穂日は，2005年は， 「わせじまん」が 7 月 16 日〜20日，「コシヒカリ」が 8 月 3 日４日，2006年は，「わせじまん」が 7 月 19 日〜20日， 「コシヒカリ」が 8 月 8 日であった.

試験には, 出穂当日, 出穂 10 日後 (2004 年の「コシヒ カリ」は 12 日後), 出穂 20 日後 (2004 年の「コシヒカリ」 は 24 日後), 出穂 30 日後（2004 年の「わせじまん」は 31 日後,「コシヒカリ」は 34 日後）の穂を用い, 処理ごとに 同じ出穂日の穂を用いた。穂の状態は, 出穂 10 日後は 1/3 1/2 の籾で玄米の縦伸長が完了した状態, 出穂 20 日後 は玄米の肥大が完了して穂の $1 / 4 \sim 1 / 3$ の粐が黄化した状態, 出穂 30 日後はすべての籾が黄化して穂軸, 枝梗は緑色の 状態であった。

幼虫放飼当日に，室内にイネを持ち込み，所定の登熟段 階の穂とそれに付随する止葉, 次葉をナイロンゴース（長 さ $53 \mathrm{~cm}$, 幅 $10 \mathrm{~cm}$ ) で覆い, 次葉葉鞘部で袋を閉じた。こ の中に, ふ化 24 時間以内の幼虫 10 頭を放飼した. 各処理 は, 2004 年, 2005 年は 6 反復, 2006 年は 12 反復とした 2006 年の「わせじまん」の出穂 10 日後と出穂 20 日後の試 験では, 穂を切除し菱葉のみとした処理（各 6 反復）も

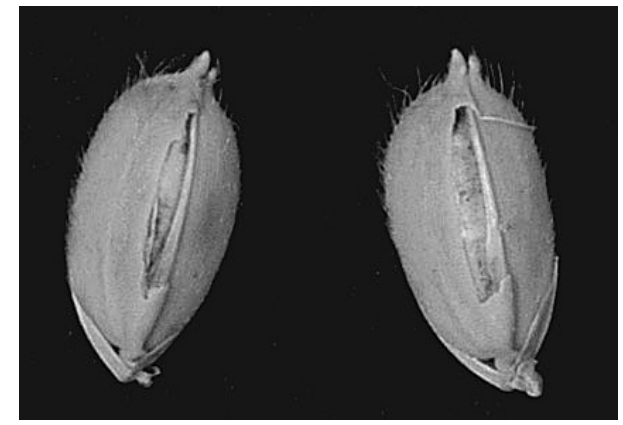

Fig. 1. Paddies with an edge of the lemma cut off.

行った.

放飼 10 日後に幼虫放飼した部位を次葉葉鞘部で切り取 り, 生存個体数とその齢期を調查した。 その後, 穂を自然 乾燥し, 総籾数と割れ籾数を調查し, また, 籾を正常籾, 割れ籾に分け，籾殼を除いたのちに玄米の被害の有無を調 查した，割れ籾は内穎と外穎の鈎合部が裂開している籾と 鈎合部にずれがある籾とし, 被害粒は変色部がある玄米と した.

\section{3. 正常籾および割れ籾における幼虫発育}

2005 年に, 正常籾のみ, 割れ籾のみとした穂を用いて, 生存個体数を比較した. 品種は「わせじまん」と「コシヒ カリ」で, 出穂 20 日後, 出穂 30 日後の穂を供試した。 ネは, 上記試験の 2005 年と同じように栽培し，放飼当日 に室内に持ち込み，正常籾のみ，割れ粐のみを約 20 粒残 し, 他の籾は切除した.「コシヒカリ」の出穂 20 日後頃の 穂では, 割れ籾がほとんどなかったことから, 外穎の縁を 鈎合部に沿って幅 $1 \mathrm{~mm}$ 程度, 籾の長さの $3 / 4$ 程度にわ たって切除し，玄米を露出させた料（Fig. 1）を割れ籾と して扱った。 また，「わせじまん」の出穂 20 日後では正常 籾が少なかったため, 割れ粉のみの試験とした。

幼虫の放飼ならびに調查は, 上記試験と同じように行っ た。

結果

\section{1. 品種, 登熟段階が異なる穂における幼虫発育}

2005 年の「わせじまん」の出穂日放飼は, イネへのナイ ロンゴース製の袋のかけかたに不備があり, 籾数が著しく 少なくなったため，そのデータは除外した。

割れ籾調查, 被害粒調查の結果を Table 1 に示した。 2004 年は, 「わせじまん」では, 割れ籾数は, 出穂日が 0 で, 出穂 10 日後, 出穂 20 日後は極めて少なく, 出穂 31 日後にわずかに増加し, また, 被害粒数は, 出穂日は 3.2 粒で, 出穂 10 日後, 出穂 20 日後は極めて少なく, 出穂 31 日後にやや増加した。「コシヒカリ」では, 割れ籾数, 被 害粒数の推移は,「わせじまん」と同様の傾向を示した。 2005 年, 2006 年は,「わせじまん」では, 割れ粉数は, 出 
Table 1. Number of total paddies, split-hull paddies and injured grains at different ripening stages of two rice cultivars in the experiment of rearing nymphs of T. caelestialium $^{\text {a }}$

\begin{tabular}{|c|c|c|c|c|c|c|c|c|c|}
\hline \multirow{3}{*}{$\begin{array}{l}\text { Year } \\
2004\end{array}$} & \multirow{3}{*}{$\begin{array}{c}\text { Cultivar } \\
\text { Wasejiman }\end{array}$} & \multirow{3}{*}{$\begin{array}{c}\begin{array}{c}\text { Ripening } \\
\text { stage }^{\mathrm{b}}\end{array} \\
0\end{array}$} & \multirow{3}{*}{$\begin{array}{c}\begin{array}{c}\text { No. of } \\
\text { total paddies }\end{array} \\
46.3\end{array}$} & \multirow{2}{*}{\multicolumn{2}{|c|}{$\begin{array}{c}\text { No. of } \\
\text { split-hull paddies }^{\mathrm{c}} \\
( \pm \mathrm{SE})\end{array}$}} & \multicolumn{4}{|c|}{ No. of injured grains ${ }^{c}$} \\
\hline & & & & & & \multirow{2}{*}{$\begin{array}{c}\text { Normal paddies } \\
3.2\end{array}$} & \multirow{2}{*}{$\begin{array}{c}\text { Split-hull paddies } \\
0\end{array}$} & \multicolumn{2}{|c|}{ Total $( \pm \mathrm{SE})$} \\
\hline & & & & 0 & & & & $3.2 \pm 0.9$ & $(6.8)$ \\
\hline & & 10 & 55.5 & $0.3 \pm 0.2$ & $(0.6)$ & 0 & 0.2 & $0.2 \pm 0.2$ & $(0.3)$ \\
\hline & & 20 & 57.7 & $0.2 \pm 0.2$ & $(0.3)$ & 0.2 & 0 & $0.2 \pm 0.2$ & $(0.3)$ \\
\hline & & 31 & 50.2 & $5.5 \pm 1.5$ & (11.0) & 0.2 & 3.8 & $4.0 \pm 1.1$ & $(8.1)$ \\
\hline & Koshihikari & 0 & 82.0 & 0 & & 4.5 & 0 & $4.5 \pm 2.5$ & $(6.5)$ \\
\hline & & 12 & 71.5 & $1.0 \pm 0.0$ & (1.4) & 0 & 0.3 & $0.3 \pm 0.2$ & $(0.5)$ \\
\hline & & 24 & 66.5 & $1.0 \pm 0.4$ & (1.8) & 0.3 & 1.0 & $1.3 \pm 0.6$ & $(2.3)$ \\
\hline & & 34 & 56.2 & $2.5 \pm 1.0$ & (4.3) & 0 & 2.0 & $2.0 \pm 0.9$ & (3.4) \\
\hline \multirow[t]{7}{*}{2005} & Wasejiman & 10 & 67.2 & $0.5 \pm 0.2$ & $(0.9)$ & 1.3 & 0.2 & $1.5 \pm 0.6$ & $(2.4)$ \\
\hline & & 20 & 66.7 & $34.2 \pm 5.4$ & $(51.2)$ & 2.7 & 32.3 & $35.0 \pm 4.9$ & $(52.5)$ \\
\hline & & 30 & 61.8 & $45.3 \pm 3.7$ & (74.3) & 1.2 & 35.0 & $36.2 \pm 6.1$ & $(59.2)$ \\
\hline & Koshihikari & 0 & 86.8 & 0 & & 2.3 & 0 & $2.3 \pm 0.7$ & $(3.0)$ \\
\hline & & 10 & 84.3 & 0 & & 0.3 & 0 & $0.3 \pm 0.3$ & $(0.5)$ \\
\hline & & 20 & 90.0 & $2.7 \pm 1.0$ & (2.9) & 3.5 & 2.3 & $5.8 \pm 2.5$ & (6.7) \\
\hline & & 30 & 76.0 & $15.5 \pm 2.9$ & $(20.2)$ & 0.7 & 11.7 & $12.3 \pm 2.4$ & $(15.9)$ \\
\hline \multirow[t]{8}{*}{2006} & Wasejiman & 0 & 89.1 & 0 & & 4.0 & 0 & $4.0 \pm 0.6$ & $(4.5)$ \\
\hline & & 10 & 87.8 & $1.0 \pm 0.3$ & (1.1) & 1.2 & 0.6 & $1.8 \pm 1.0$ & $(1.8)$ \\
\hline & & 20 & 89.0 & $53.9 \pm 3.7$ & (60.4) & 0.8 & 49.6 & $50.3 \pm 3.4$ & $(56.5)$ \\
\hline & & 30 & 92.2 & $81.3 \pm 2.7$ & (88.3) & 0.2 & 54.3 & $54.5 \pm 3.0$ & $(59.0)$ \\
\hline & Koshihikari & 0 & 112.1 & 0 & & 5.9 & 0 & $5.9 \pm 1.2$ & (5.3) \\
\hline & & 10 & 105.1 & $0.2 \pm 0.1$ & $(0.2)$ & 0.2 & 0.2 & $0.3 \pm 0.2$ & $(0.3)$ \\
\hline & & 20 & 104.0 & $1.9 \pm 0.6$ & (1.8) & 0.5 & 1.5 & $2.0 \pm 0.7$ & (1.9) \\
\hline & & 30 & 104.3 & $5.8 \pm 1.4$ & (5.9) & 0.7 & 3.9 & $4.6 \pm 1.4$ & (4.6) \\
\hline
\end{tabular}

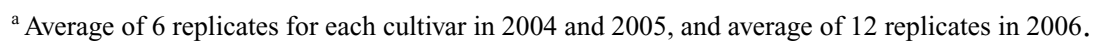

${ }^{\mathrm{b}}$ Days after heading.

${ }^{\mathrm{c}}$ Figures in parentheses indicate percentages of total paddies.

穂 20 日後，出穂 30 日後に著しく増加し，また，被害粒数 も同様に増加し，そのほとんどは割れ籾であった。「コシ ヒカリ」でも, 割れ籾数, 被害粒数は, 出穂 20 日後, 出 穂 30 日後に増加したが, 「わせじまん」に比べいずれも少 なかった。いずれの年次, 品種に打いても, 被害粒は, 正 常籾の大部分が頂部被害粒, 割れ籾の大部分が側部被害粒 であった。

幼虫生存数調査の結果を Table 2 に示した。 2004 年は, 登熟段階間の生存率の差異は有意であった（逆正弦変換後 に二元配置分散分析, 品種: $F=0.6, p=0.440$; 登熟段階： $F=30.9, p<0.001$; 交互作用 : $F=3.0, p=0.041)$.「わせじま ん」,「コシヒカリ」のいずれでも, 生存率は, 出穂日が高 く，その後の登熟段階では低かった（逆正弦変換後に Tukey 法, $p<0.05) 。 2005$ 年は, 品種間, 登熟段階間の生 存率の差異は有意であった（出穂日を除く 3 つの登熟段階 で検定, 品種： $F=20.9, p<0.001 ;$ 登熟段階： $F=39.8$, $p<0.001$; 交互作用： $F=11.2, p<0.001)$.「わせじまん」で の生存率は, 出穂 20 日後が高く, 次いで出穂 30 日後であ
り, 出穂 10 日後は低かった。「コシヒカリ」での生存率は, 出穂日が高く，その後の登熟段階では低かった。また，「コ シヒカリ」の出穂 20 日後, 出穂 30 日後の生存率は「わせ じまん」に比べ低かった。 2006 年は, 品種間, 登熟段階間 の生存率の差異は有意であった（品種： $F=70.3, p<0.001$; 登熟段階： $F=206.0, p<0.001$; 交互作用： $F=46.7$, $p<0.001)$.「わせじまん」での生存率は, 出穂 20 日後, 出 穂 30 日後, 出穂日, 出穂 10 日後の順であり, それぞれの 差異は有意であった。「コシヒカリ」の生存率は, 出穂日 が高く，その後の登熟段階では低かった。「わせじまん」の 茎葉のみとした場合の生存率は, 出穂 10 日後, 出穂 20 日 後のいずれも $0 \%$ であった.いずれの年次, 品種において も，生存個体率が高いほど，より高い齢期の個体の割合が 高い傾向が認められた。

各登熟段階に打ける被害粒数と生存個体率の関係を Fig. 2 に示した。出穂日では両者の間に有意な関係は認められ なかったが, その後の登熟段階では被害粒数が多いほど生 存個体率が高く, 特に出穂 20 日後と出穂 30 日後では密接 
Table 2. Survival rates of T. caelestialium nymphs at different ripening stages of two rice cultivars ${ }^{\mathrm{a}}$

\begin{tabular}{|c|c|c|c|c|c|c|c|c|}
\hline \multirow{2}{*}{ Year } & \multirow{2}{*}{ Cultivar } & \multirow{2}{*}{ Ripening stage ${ }^{b}$} & \multirow{2}{*}{$\begin{array}{l}\text { Survival rate }(\%) \\
\qquad( \pm \mathrm{SE})^{\mathrm{c}}\end{array}$} & \multicolumn{5}{|c|}{ Nymphal instar (\%) } \\
\hline & & & & $1 \mathrm{st}$ & 2 nd & $3 \mathrm{rd}$ & 4 th & 5 th \\
\hline \multirow[t]{8}{*}{2004} & Wasejiman & 0 & $53.3 \pm 11.2 \mathrm{a}$ & 0 & 0 & 16 & 81 & 3 \\
\hline & & 10 & $1.7 \pm 1.7 \quad b$ & 0 & 0 & 100 & 0 & 0 \\
\hline & & 20 & $1.7 \pm 1.7 \quad b$ & 0 & 0 & 100 & 0 & 0 \\
\hline & & 31 & $3.3 \pm 2.1 \quad b$ & 0 & 0 & 100 & 0 & 0 \\
\hline & Koshihikari & 0 & $26.7 \pm 7.6 \quad \mathrm{a}$ & 0 & 0 & 100 & 0 & 0 \\
\hline & & 12 & $0 \quad \mathrm{~b}$ & & & & & \\
\hline & & 24 & $8.3 \pm 4.0 \quad b$ & 0 & 0 & 60 & 40 & 0 \\
\hline & & 34 & $3.3 \pm 3.3 \quad b$ & 0 & 0 & 100 & 0 & 0 \\
\hline \multirow[t]{7}{*}{2005} & Wasejiman & 10 & 0 & & & & & \\
\hline & & 20 & $75.0 \pm 7.2 \mathrm{a}$ & 0 & 0 & 18 & 76 & 7 \\
\hline & & 30 & $36.7 \pm 10.2 \mathrm{~b}$ & 0 & 0 & 36 & 64 & 0 \\
\hline & Koshihikari & 0 & $71.7 \pm 9.5 \quad \mathrm{a}$ & 0 & 0 & 2 & 74 & 23 \\
\hline & & 10 & $\mathrm{c}$ & & & & & \\
\hline & & 20 & $16.7 \pm 8.0 \quad b c$ & 0 & 10 & 90 & 0 & 0 \\
\hline & & 30 & $20.0 \pm 2.6 \quad b$ & 0 & 8 & 92 & 0 & 0 \\
\hline \multirow[t]{10}{*}{2006} & Wasejiman & 0 & $47.5 \pm 5.7 \quad \mathrm{c}$ & 0 & 0 & 4 & 86 & 11 \\
\hline & & 10 & $0.8 \pm 0.8 \mathrm{~d}$ & 0 & 0 & 0 & 0 & 100 \\
\hline & & 20 & $89.2 \pm 2.6 \quad \mathrm{a}$ & 0 & 0 & 4 & 45 & 51 \\
\hline & & 30 & $76.7 \pm 3.8 \quad b$ & 0 & 0 & 13 & 84 & 3 \\
\hline & Koshihikari & 0 & $30.8 \pm 5.0 \quad \mathrm{a}$ & 0 & 0 & 8 & 89 & 3 \\
\hline & & 10 & 0 & & & & & \\
\hline & & 20 & $5.0 \pm 1.9 \mathrm{~b}$ & 0 & 0 & 67 & 33 & 0 \\
\hline & & 30 & $10.0 \pm 4.6 \quad b$ & 0 & 0 & 75 & 25 & 0 \\
\hline & Wasejiman & 10 & 0 & & & & & \\
\hline & (without ear) $^{\mathrm{d}}$ & 20 & 0 & & & & & \\
\hline
\end{tabular}

${ }^{\mathrm{a}, \mathrm{b}}$ See footnotes of Table 1.

${ }^{c}$ Values with same letter are not significantly different by Tukey's test ( $p>0.05$, Data were transformed by Arcsin transformation).

${ }^{\mathrm{d}}$ The ear was cut off. Average of 6 replicates.

な関係が認められた。

出穂 20 日後, 出穂 30 日後における割れ籾数と生存個体 率の関係を Fig. 3 に示した。いずれにおいても，割れ籾数 が多いほど生存個体率が高かった。

\section{2. 正常籾および割れ籾における幼虫発育}

正常籾のみとした穂, 割れ籾のみとした穂での幼虫発育 試験の結果を Table 3, Table 4 に示した。正常籾のみとした 穂においても，放飼期間終了時には，わずかに割れ籾が認 められた。「わせじまん」,「コシヒカリ」のいずれも，割 れ籾のみとした穂ではほとんどの籾が被害粒であったが， 正常籾のみとした穂では被害粒は少なかった。「わせじま ん」では, 出穂 20 日後では, 割れ籾のみとした穂におけ る幼虫の生存率は, 正常籾のみの穂に比べ明らかに高かっ た（逆正弦変換後に $t$ 検定， $p<0.001 ）$.「コシヒカリ」で は, 出穂 20 日後, 出穂 30 日後のいずれでも, 割れ籾のみ とした穂に打ける生存率は，正常籾のみの穂に比べ明らか
に高かった。

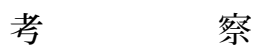

石本（2004a）は，アカヒゲホソミドリカスミカメの水 田におけるすくい取り調查により, 登熟中 ・後期の幼虫数 は, 極早生の「わせじまん」で多く, 中生の「コシヒカリ」 で少ないことを認めた。この報告において，成熟期の割れ 籾率は，「わせじまん」が $2.3 \sim 18.0 \%$ ，「コシヒカリ」が $0.8 \sim 1.6 \%$ であり, 割れ籾率の違いによる幼虫生存率の違 いが，幼虫数の違いの要因の一つであると考えられた．割 れ籾の発生始期は，新潟県では出穂期の 10 15 日後（石 本, 2004a; 石本・永瀬，2005）, 北海道では出穂期の 15 日後ないし 20３0日後（黒蝕米対策研究班，1975）であ り，その後登熟に伴い割れ籾数は増加する。本試験では, 割れ籾は, 出穂 10 日後には極めて少なく, その後登熟に 伴い増加し，増加の程度は年次，品種により異なった。ま 


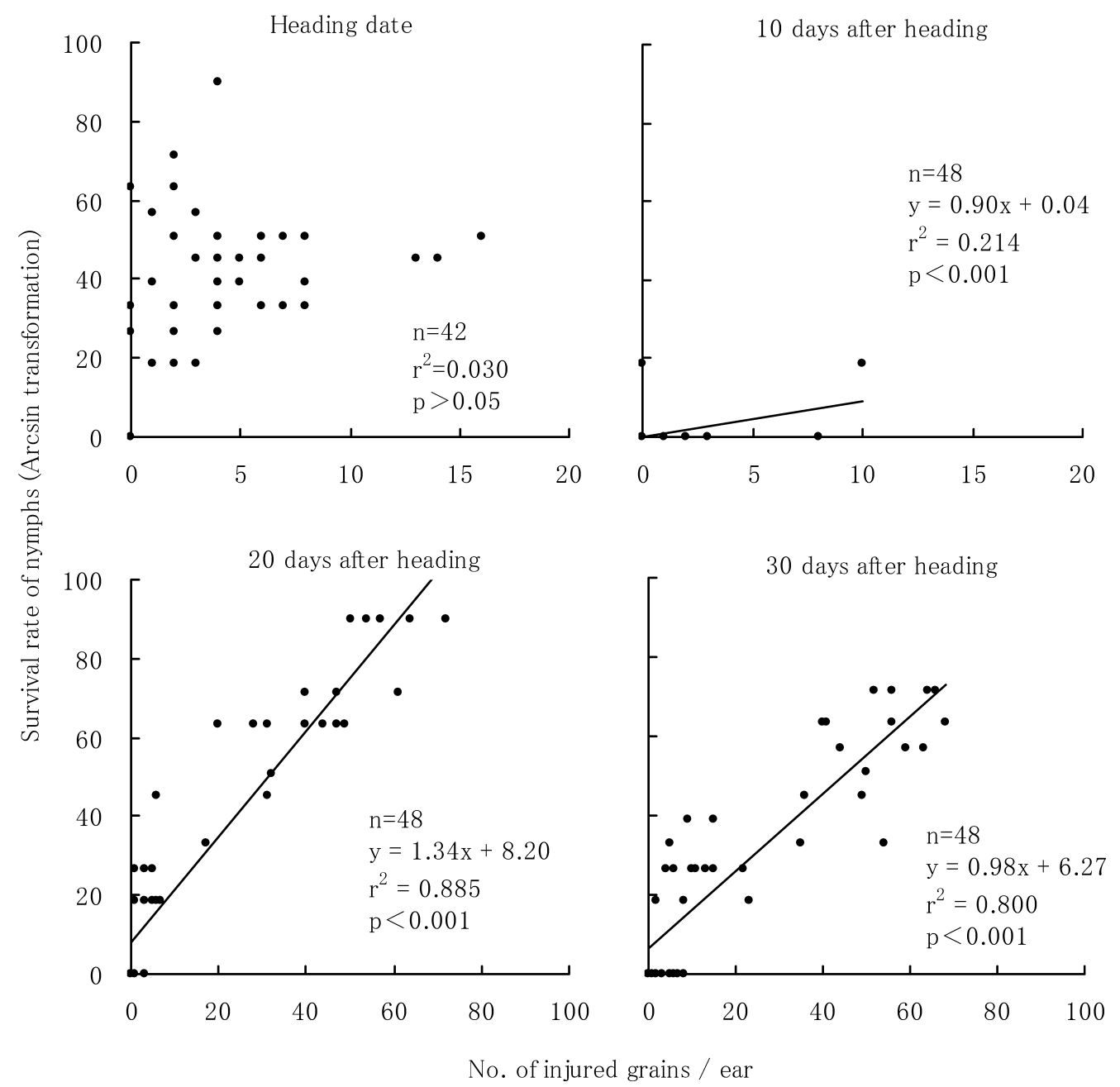

Fig. 2. Relationship between number of injured grains and survival rate of T. caelestialium nymphs on two cultivars at different ripening stages.
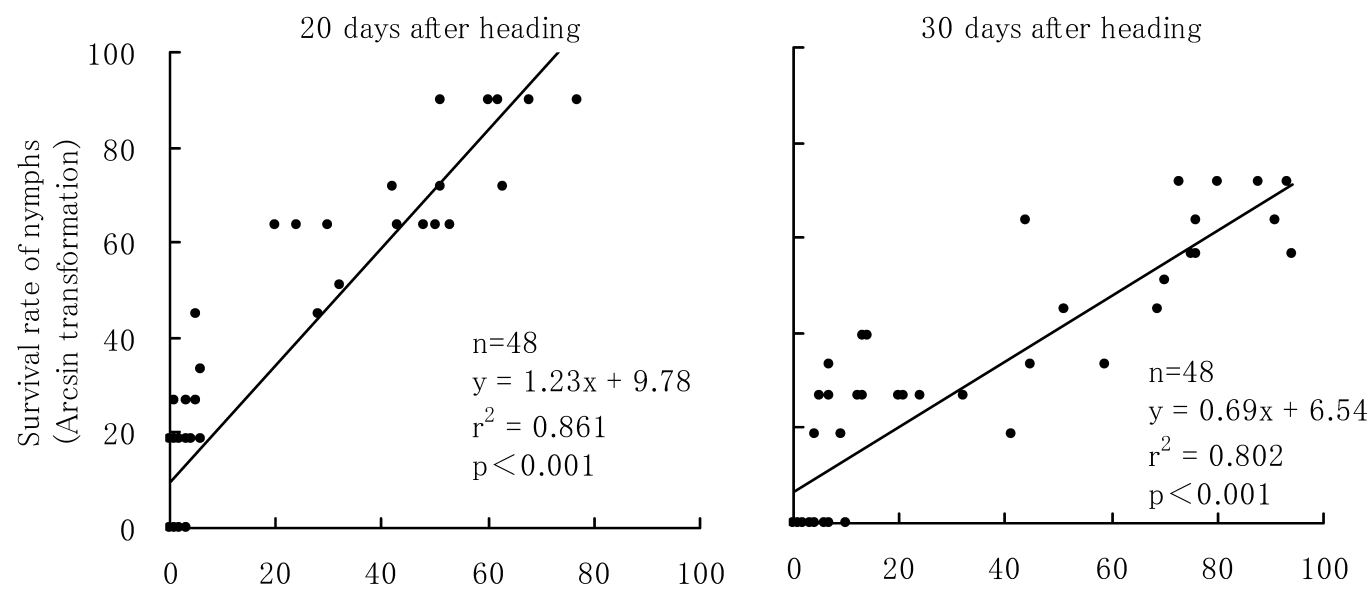

No. of split-hull paddies / ear

Fig. 3. Relationship between number of split-hull paddies and survival rate of T. caelestialium nymphs on two cultivars at different ripening stages. 
Table 3. Number of total paddies, split-hull paddies and injured grains in the experiment of rearing nymphs of T. caelestialium on rice with an ear consisting of normal paddies alone or split-hull paddies alone ${ }^{\mathrm{a}}$

\begin{tabular}{|c|c|c|c|c|c|c|c|}
\hline \multirow[b]{2}{*}{ Cultivar } & \multirow{2}{*}{$\begin{array}{l}\text { Ripening } \\
\text { stage }^{\mathrm{b}}\end{array}$} & \multirow[b]{2}{*}{ Type of ear } & \multirow{2}{*}{$\begin{array}{l}\text { No. of total } \\
\text { paddies }\end{array}$} & \multicolumn{2}{|c|}{ No. of split-hull paddies } & \multicolumn{2}{|c|}{ No. of injured grains } \\
\hline & & & & $\begin{array}{l}\text { Beginning of } \\
\text { rearing period }\end{array}$ & $\begin{array}{c}\text { End of } \\
\text { rearing period }\end{array}$ & $\begin{array}{l}\text { Normal } \\
\text { paddies }\end{array}$ & $\begin{array}{c}\text { Split-hull } \\
\text { paddies }\end{array}$ \\
\hline \multirow{3}{*}{ Wasejiman } & 20 & Normal paddies alone & 21.5 & 0 & 2.0 & 3.0 & 1.7 \\
\hline & & Split-hull paddies alone & 19.5 & 19.5 & 19.5 & & 19.3 \\
\hline & 30 & Split-hull paddies alone & 19.8 & 19.8 & 19.8 & & 18.3 \\
\hline \multirow[t]{4}{*}{ Koshihikari } & 20 & Normal paddies alone & 20.0 & 0 & 0.2 & 1.3 & 0.2 \\
\hline & & Split-hull paddies alone ${ }^{c}$ & 19.8 & 19.8 & 19.8 & & 19.2 \\
\hline & 30 & Normal paddies alone & 19.8 & 0 & 0.3 & 0 & 0 \\
\hline & & Split-hull paddies alone & 20.2 & 20.2 & 20.2 & & 16.5 \\
\hline
\end{tabular}

${ }^{\text {a }}$ Average of 6 replicates.

${ }^{\mathrm{b}}$ Days after heading.

${ }^{\mathrm{c}}$ Paddies with an edge of the lemma cut off.

Table 4. Survival rates of $T$. caelestialium nymphs on rice with an ear consisting of normal paddies alone or split-hull paddies alone $\mathrm{a}^{\mathrm{a}}$

\begin{tabular}{|c|c|c|c|c|c|c|c|c|}
\hline \multirow{2}{*}{ Cultivar } & \multirow{2}{*}{$\begin{array}{l}\text { Ripening } \\
\text { stage }^{b}\end{array}$} & \multirow{2}{*}{ Type of ear } & \multirow{2}{*}{$\begin{array}{l}\text { Survival rate }(\%)^{\mathrm{d}} \\
\quad( \pm \mathrm{SE})\end{array}$} & \multicolumn{5}{|c|}{ Nymphal instar (\%) } \\
\hline & & & & $1 \mathrm{st}$ & 2nd & $3 \mathrm{rd}$ & 4 th & 5 th \\
\hline \multirow[t]{3}{*}{ Wasejiman } & 20 & Normal paddies alone & $11.7 \pm 4.8$ & 0 & 0 & 57 & 43 & 0 \\
\hline & & Split-hull paddies alone & $75.0 \pm 5.0^{* * *}$ & 0 & 0 & 18 & 80 & 2 \\
\hline & 30 & Split-hull paddies alone & $73.3 \pm 2.1$ & 0 & 2 & 55 & 43 & 0 \\
\hline \multirow[t]{4}{*}{ Koshihikari } & 20 & Normal paddies alone & $1.7 \pm 1.7$ & 0 & 0 & 100 & 0 & 0 \\
\hline & & Split-hull paddies alone ${ }^{c}$ & $70.0 \pm 4.5^{* * *}$ & 0 & 0 & 76 & 24 & 0 \\
\hline & 30 & Normal paddies alone & 0 & & & & & \\
\hline & & Split-hull paddies alone & $31.7 \pm 6.5^{* * *}$ & 0 & 21 & 68 & 11 & 0 \\
\hline
\end{tabular}

a,b,c See footnotes of Table 3 .

${ }^{\mathrm{d}}$ Values with ${ }^{* * *}$ are significantly different by $t$ test $(p<0.001$, Data were transformed by Arcsin transformation).

た，出穂 30 日後の放飼における放飼終了時の割れ籾率は, 「わせじまん」では特に高く，幼虫発育と割れ粐との関係 を検討するには適当な条件と考えられた。

出穂日の生存率は $26.7 \sim 71.7 \%$ で, 比較的高かった。 こ の登熟段階では，割れ籾の発生はなく，被害粒はすべて正 常粐であったが，この被害粒数と生存率には有意な関係は 認められなかった。本種は，正常籾では籾頂部の鈎合部か ら玄米を吸汁するが（伊藤，2004），玄米は開花 6 日後頃 に料款内の天井に届くことから（星川，1975），放飼直後 の時期は玄米が未発達で, 幼虫が籾頂部から玄米を加害で きる籾はなかったと推察される。したがって，幼虫は玄米 のみでなく，少なくとも一時的には，玄米以外の部位，例 えば出穂直後の軟弱な状態の頴や萂を飭として利用してい る可能性も考えられる.
出穂 10 日後の幼虫生存率はいずれの年次, 品種でも極 めて低く, 被害粒は少なかった。出穂 20 日後, 30 日後の 幼虫生存率, 被害粒数は年次, 品種による変動が大きかっ たが，幼虫生存率は被害粒が多いほど高かった，穂を切除 し, 茎葉のみとしたイネでは, 生存個体は認められなかっ た。玄米は幼虫の好適な慨であり, 茎葉のみでは慨として 不十分でも，玄米を一緒に与えると成虫まで発育する（石 本・佐藤，2006）。したがって，これら３つの登熟段階の イネに打いて, 玄米の吸汁量が幼虫生存率の主な変動要因 と考えられる。また，被害粒は割れ粐の割合が高く，割れ 籾数が多いほど幼虫生存率が高かったことから, 幼虫は主 として割れ粐から玄米を吸汁すると考えられる。

出穂 20 日後, 30 日後のイネで, 割れ粐のみまたは正常 籾のみとした穂における幼虫生存率を比較した結果, 正常 
籾のみの穂では生存率が著しく低く，被害粒数も極めて少 なかった。したがって，幼虫は正常粐から立米を吸汁する ことは困難と考えられる。

以上のことから，登熟期のイネに打ける幼虫の発育には 穂の登熟段階と割れ籾数が影響し, 出穂直後のイネと割れ 籾の多いイネが飭として好適と考えられる. 水田における 幼虫の主な発生時期は登熟中・後期であることから，その 時期の幼虫の発育には割れ籾の発生が影響し, 割れ籾の発 生時期が早く, 発生量が多い条件で幼虫の発生量が多くな りやすいと考えられる。

割れ籾の発生は, 品種, 気象条件, 肥料条件などによっ て変動することから（松浦ら，1967；松浦・岩田，1968; 寺西ら，1981; 伊藤，2004）, 割れ籾の発生時期や発生量 が, 水田に打ける登熟中・後期の幼虫発生量の変動要因の 一つである可能性が高い. 本種の予防的な薬㓣防除法は, すでに明らかにされており，今後は成・幼虫の発生量に応 じて防除要否を判断する技術を構築する必要がある（石 本, 2006)。そこでは, 高精度で登熟中・後期の幼虫発生 量を予測する必要があり，そのためには幼虫発生量に及ぼ す割れ粐発生の影響を解明することは重要と思われる.

伊藤（2004）は, 網かけした穂への成虫放飼試験の結果 に基づき，割れ籾を少なくすることによる斑点米発生抑制 効果には限界があるとし, その理由として, 登熟前期の籾 先端部からの加害により斑点米が発生することを挙げてい る. 一方, 水田に打けるすくい取り調查, 斑点米調查の結 果から, 水田への成虫侵入時期は登熟初期に限定され, そ の発生期間も短いため, 侵入成虫の加害による斑点米の発 生は少なく, 水田内で増殖した世代の幼・成虫の加害によ る側部斑点米が斑点米の大部分であることが示されている (石本，2004a）。また，この幼・成虫密度と斑点米率には 密接な関係があることも示されている（石本，2004b；石 本・永瀬, 2005)。したがって, 水田内で発生する幼虫密 度を低下させることは, 斑点米発生抑制に有効であること は明らかである。本試験の結果から, 割れ粐が少ないイネ では, 幼虫の生存率が低下し, その結果として幼虫密度は 低下すると考えられ，割れ粐の発生抑制は，本種による斑 点米発生抑制に有効と考えられる。

\section{摘要}

登熟期のイネに打けるアカヒゲホソミドリカスミカメ幼 虫の発育に対するイネの登熟段階と割れ粐発生の影響を明 らかにするため, 割れ籾が多い品種「わせじまん」と割れ 籾が少ない品種「コシヒカリ」を用いて, 出穂日, 出穂 10 日後, 出穂 20 日後, 出穂 30 日後の各登熟段階のイネに 1 齢幼虫を放飼し, 放飼 10 日後の生存個体数と被害粒数, 割れ籾数を調査した。割れ籾数は, 出穂日は 0 , 出穂 10 日 後はわずかであり, 幼虫生存率は, 出穂日は高く, 出穂 10
日後は低かった。出穂 20 日後, 30 日後では年次による変 動はあったが，「わせじまん」で幼虫生存率が高く，割れ 籾数も多かった. 出穂 20 日後, 30 日後の被害粒数と幼虫 生存率の間には有意な正の関係が認められ, 幼虫の発育に は玄米の吸汁が密接に関係していると考えられた。この被 害粒のほとんどは割れ籾であり, 割れ籾数と幼虫生存率の 間には有意な正の関係が認められたことから, 玄米の吸汁 は主として割れ籾からであり, 幼虫発育には割れ籾の発生 が密接に関係していると考えられた。割れ籾の発生時期・ 発生量が水田に打ける幼虫発生量の変動要因の一つである 可能性が示唆された.

\section{引用文献}

八谷和彦 (1985) アカヒゲホソミドリメクラガメの要防除水 準. 北海道立農試集報 53: 43-49. [Hachiya, K. (1985) Control threshold of rice leaf bug (Trigonotylus coelestialium Kirkaldy). Bull. Hokkaido Prefect. Agric. Exp. Stn. 53: 43-49.]

樋口博也・高橋明彦 (2000) アカヒゲホソミドリカスミカメの小 麦苗による飼育. 北陸病虫研報 48: 23-25. [Higuchi, H. and A. Takahashi (2000) Method of rearing the rice leaf bug, Trigonotylus caelestialium (Kirkaldy) (Heteroptera: Miridae) with wheat seedlings. Proc. Assoc. Plant Prot. Hokuriku 48: 23-25.]

星川清親 (1975) イネの生長. 農山漁村文化協会, 東京. $317 \mathrm{pp}$. [Hoshikawa, K. (1975) The Growing Rice Plant. Rural Culture Association, Tokyo. 317 pp.]

石本万寿広 (2004a) アカヒゲホソミドリカスミカメの水田内発生 消長. 応動昆 48: 79-85. [Ishimoto, M. (2004a) Seasonal prevalence of occurrence of the rice leaf bug, Trigonotylus caelestialium (Kirkaldy) (Heteroptera: Miridae) on paddy rice plants. Jpn. J. Appl. Entomol. Zool. 48: 79-85.]

石本万寿広 (2004b) アカヒゲホソミドリカスミカメに対する各種 殺虫剂の防除効果. 北陸病虫研報 53: 29-36. [Ishimoto, M. (2004b) Control effect of insecticides on rice leaf bug, Trigonotylus caelestialium (Kirkaldy) (Heteroptera: Miridae). Proc. Assoc. Plant Prot. Hokuriku 53: 29-36.]

石本万寿広 (2006) 水田におけるアカヒゲホソミドリカスミカメ の発生消長と薬剂散布適期. 植物防疫 60: 208-210. [Ishimoto, M. (2006) Seasonal prevalence of the rice leaf bug, Trigonotylus caelestialium in paddy fields and proper application timing of insecticides to this bug. Plant Prot. 60: 208-210.]

石本万寿広・永瀬 淳 (2005) アカヒゲホソミドリカスミカメに 対する薬剂散布適期. 北陸病虫研報 54: 29-38. [Ishimoto, M. and A. Nagase (2005) Proper application timing of insecticide to the rice leaf bug, Trigonotylus caelestialium (Kirkaldy) (Heteroptera: Miridae). Proc. Assoc. Plant Prot. Hokuriku 54: 29-38.] 石本万寿広・佐藤秀明 (2006) 種子の吸汁がアカヒゲホソミドリ カスミカメの幼虫発育と産卵に及ぼす影響。応動昆 50: 305-310. [Ishimoto, M. and H. Sato (2006) Effects of supplying grains as supplementary food on development of nymphs and fecundity of adults of the rice leaf bug, Trigonotylus caelestialium (Kirkaldy) (Heteroptera: Miridae). Jpn. J. Appl. Entomol. Zool. 50: 305-310.] 
伊藤清光 (2004) アカヒゲホソミドリカスミカメの加害による斑 点米発生：特に割れ粗との関係. 応動昆 48: 23-32. [Ito, K. (2004) The role of the feeding habits of Trigonotylus caelestialium (Kirkaldy) on the production of pecky rice grains with special reference to the occurrence of split-hull paddy. Jpn. J. Appl. Entomol. Zool. 48: 23-32.]

黒蝕米対策研究班 (1975) 北海道における黒蝕米に関する研究. 北農 42: 1-90. [Anonym (1975) Studies on the pecky rice in Hokkaido. Hokuno 42: 1-90.]

松浦欣哉・福田忠夫 ·岩田忠寿・青木研一 (1967) 水稲に打ける 開頴籾発生の品種間差異と若干の栽培条件との関係. 日作紀 36: 13-15. [Matsuura, K., T. Fukuda, T. Iwata and K. Aoki (1967) Relationship of varietal differences and growing conditions of paddy rice to the occurrence of unclosed glume grains. Jpn. J. Crop Sci. 36: 13-15.]

松浦欣哉・岩田忠寿 (1968) 水稲に打ける開穎籾発生の早晚生間 差異と気象条件について. 日作北陸会報 4: 1-4. [Matsuura, K. and T. Iwata (1968) Differences of the occurrence of unclosed glume grains in earliness of variety of rice, and the relation to meteorological conditions. The Hokuriku Crop Science 4: 1-4.]

奥山七郎·井上 寿 (1974) 黒蝕米の発生とカメムシ類との関連 について一特にアカヒゲホソミドリメクラガメとの関係一. 北海道立農試集報 30: 85-94. [Okuyama, S. and H. Inouye (1974) On the relation between the occurrence of the black rot of rice grains and insects, especially the relation of rice leaf bug (Trigonotylus colestialium Kirkaldy). Bull. Hokkaido Prefect. Agric. Exp. Stn. 30: 85-94.]

寺西敏子 ·大橋幸雄 ·山元尹男 ·松下真一郎 (1981) 水稲の割れ 籾発生とその防止対策。農業及園芸 56: 661-665. [Teranishi, T., Y. Ohashi, K. Yamamoto and S. Matsushita (1981) Occurrence of split-hull paddy of rice and prevention measures. Agriculture and Horticulture 56: 661-665.]

渡邊朋也・樋口博也 (2006) 斑点米カメムシ類の近年の発生と課 題. 植物防疫 60: 201-203. [Watanabe, T. and H. Higuchi (2006) Recent occurrence and problem of rice bugs. Plant Prot. 60: 201203.] 